\title{
One Health and Antibiotic Resistance in Agroecosystems
}

\author{
Lisa M. Durso ${ }^{1}$ and Kimberly L. Cook $^{2}$ \\ ${ }^{1}$ USDA, ARS, Agroecosystem Management Research Unit, 251 Filley Hall, UNL East Campus, Lincoln, NE 68583 \\ ${ }^{2}$ USDA, ARS, Bacterial Epidemiology and Antimicrobial Resistance Research Unit, 950 College Station Rd., Athens, GA 30605
}

\begin{abstract}
Agriculture reflects One Health principals, with the job of the farmer being to sustainably balance human, animal, and soil health. It is imperative to include an agricultural perspective when addressing antibiotic resistance (AR) from a One Health perspective, as the farmers, ranchers, and agricultural professionals have an intimate working knowledge of these complex systems, and they will be on the front lines of implementing on-farm control measures. Currently, communication across the One Health triad (humans, animals, environment) regarding agricultural AR is hindered by ambiguous language, complicated by cultural and linguistic differences that can lead to the conclusion that the other participant is not aware of the facts, or has ulterior motives. This work explores and identifies the language and vocabulary of AR in the context of supporting strategic short- and long-term problem solving in a One Health context.
\end{abstract}

Keywords: Antibiotic Resistance, Agriculture, One Health, Agroecosystems, Food, Farms, Environment

"If you eat, you are involved in agriculture."

Wendell Berry (1990)

The complexity of the antibiotic resistance (AR) problem and its widespread impacts for human, animal, and environmental health make it "the quintessential One Health issue" (Robinson et al. 2016; Lammie and Hughes 2016); however, the environmental dimensions of One Health have historically been underrepresented (Barrett and Bouley 2015). Agriculture is, at its core, an embodiment of One Health principals, with the job of the farmer being to sustainably balance human, animal, and soil health. While these principles are a well-known part of the narrative for North American organic livestock and poultry

Published online: March 14, 2018

Correspondence to: Lisa M. Durso, e-mail: lisa.durso@ars.usda.gov farms, they are also an ingrained part of the conventional farmers' principles of farm-animal-family stewardship (Sullivan et al. 1996). In the context of AR, there is broad consensus that the One Health community needs to reduce transfer of antibiotic drugs, AR bacteria, and antibiotic resistance genes (AR genes) to, and through, the environment (Berendonk et al. 2015; Williams-Nguyen et al. 2016; Allen et al. 2010; Pruden et al. 2013). This consensus arises from and is coupled to the growing body of knowledge on environmental inputs of drugs, bacteria, and genes from organic (Sutherland et al. 2013; USDA 2006), natural (Syrengelas et al. 2017), and conventional food animal production (Marti et al. 2014; Cook et al. 2014; Brooks et al. 2014; McKinney et al. 2010; Sandberg and LaPara 2016; Chambers et al. 2015; Qiao et al. 2018).

From the human health perspective, it is the acquisition of multiple resistances by pathogens that is the primary concern. From an environmental perspective, the soil 
is a reservoir of $A R$ and the original source of $A R$ in the clinic (Fosberg et al. 2015). The evidence needed for causal links required to assess current and emergent AR health risks from agroecosystems remains a knowledge gap (Durso and Cook 2014; Williams-Nguyen et al. 2016; Topp et al. 2018; Franklin et al. 2016).

\section{One Health Terminology}

"If I had only one hour to solve a problem, I would spend up to two-thirds of that hour in attempting to define what the problem is."

Finley and Ziobro (1966)

The One Health community is composed of many disciplines, each with their own culture, language, and conceptual framework. One challenge in addressing AR is acknowledging that public health, animal health, and agroecosystem professionals use similar terms, but define them differently. Language shapes our thoughts, influences how we understand cause and effect, and impacts how groups assign blame. (Agar 2006; Fausey and Boroditsky 2010; Fausey and Matlock 2011; Thomas and McDonagh 2013). Research shows effective problem solving requires identifying terms where the participating groups have differences of interpretation, sometimes termed "rich points" (Lederach 1991; Wilkinson and Eidinow 2008; Agar 2006). These differences are often attributable to specific associations and connotations that are characteristic of individual disciplines. Ambiguity of terms across disciplinary cultures hinders strategic communications (Ramirez et al. 2008; Wilkinson and Eidinow 2008) and, at the extreme, may lead to conclusions that the other participant has made an error, is not aware of the facts, or has ulterior motives (Agar 2006). An unambiguous shared vocabulary supports rigorous reasoning and is the foundation for strategic transdisciplinary problem solving (Thompson 2009; Groysberg and Slind 2012; Knapp et al. 2015).

One example of a "rich point" in the One Health AR sphere is the term "resistance." In clinical settings, resistance is always linked to a pathogenic bacterial isolate and the threat to human or animal health is direct (Berendonk et al. 2015). Clinical resistance is measured by standardized assays to determine minimum inhibitory concentrations of an antibiotic necessary to achieve positive treatment outcomes for specific disease-causing bacteria (CLSI 2017). In contrast, most agricultural and environmental bacteria are not pathogens, the term "resistant" can be applied either to an isolate, or to a whole community of bacteria, and the threat to health is indirect (Williams-Nguyen et al. 2016). There is no consensus or standardized methods for defining or determining AR in non-clinical settings (Berendonk et al. 2015; McLain et al. 2016; Durso and Schmidt 2018), and the detection of any part of any target gene or determinant DNA sequence results in the sample being described as "resistant." Where possible, researchers use clinical standards, but the relevance of those methods and links to risk (i.e., disease outcomes) are not known for most environmental bacteria (Williams-Nguyen et al. 2016; McLain et al. 2016). Though cumbersome, the use of qualifiers such as "clinical resistance" or "environmental resistance" would provide vocabulary to distinguish the two concepts when working in a One Health setting.

As a second example, the term "environment" itself has different common uses in the human health community compared to the environmental health community, particularly in the context of AR. In human health settings, "the environment" is generally conceptualized as anything outside of the patient and is usually used in the context of the patient room, or other hospital settings (Cheng et al. 2018). This contrasts with the broader, agriculturally relevant definition of "the environment"-defined as soil, water, and air (Durso and Cook 2014; Berendonk et al. 2015). Here, qualifiers such as "built environment" and "natural environment," while not completely accurate in all instances, may provide a useful means of clearly communicating across the One Health triad.

In a final example of how the adoption of more precise language is essential to the effective communication needed for a One Health approach, it is common, particularly when discussing antibiotic use in food production, to attribute agricultural AR to the "overuse," "misuse," "unnecessary use," and "abuse" of antibiotics (Jørgensen et al. 2017; Jia et al. 2015). However, any use of antibiotics can select for resistance. According to the CDC (2013), even prudent use of antibiotics still provides selective pressure for development of resistance. The difference between "overuse" and "use" is an implied message of blame, and of a known solution - that if only the drugs were used properly, resistance would not be a problem. This imprecision in language results in a subtle but real barrier hindering strategic communication across disciplines and masks a growing body of evidence suggesting prudent use is 
necessary, but not sufficient to address AR in agroecosystems (Seiler and Berendonk 2012).

\section{Drugs, Bacteria, and Genes IN THE ENVIRONMENT}

\section{"When you can measure what you are speaking about \\ ... you know something about it." \\ William Thomson aka Lord Kelvin (1889)}

When evaluating AR in the environment, it is essential to clearly convey which AR component is being measured and discussed; drugs, bacteria, or genes (Durso and Cook 2014). It is common to measure a small set of targets, and then talk about the results using the general term "antibiotic resistance." However, it is clear that different drug classes, and their associated AR bacteria and genes, each have their own ecologies (Durso et al. 2016). The lack of resolution in terminology can cause confusion and hinder strategic communication. As an example, imagine discussing the impacts of food on human health, when, regardless of what category of food was evaluated, the strategic and policy discussions evaluated the outcomes only at the level of "food."

Of note, antibiotic drugs and their bioactive breakdown products, though not technically considered "antibiotic resistance" themselves, are widely considered the primary driver of AR (Subbiah et al. 2016), and discussions seeking to address agricultural and environmental resistance are frequently focused on the presence of anthropogenically controlled drugs in environmental matrices (Ashbolt et al. 2013; Subbiah et al. 2016; Aga et al. 2016; Amarakoon et al. 2016). There are 183 drugs listed as critically important for human medicine by the World Health Organization (WHO 2016), each carried by a multitude of bacteria, and coded for by hundreds of genes. Precision when discussing these targets is essential, because the choice of target can influence the conclusions that are being drawn about resistance in a study. For example, in a survey of tetracycline genes in native prairie soils $50 \%$ of the prairies were positive for $\operatorname{tet}(\mathrm{B})$, compared to $95 \%$ positive for tet $(\mathrm{D})$. Different conclusions would likely be drawn if tet(B) were used to assess resistance compared to tet(D) (Durso et al. 2016).

Another "rich point" in One Health AR discussions is the role of antibiotic drugs as a driver of AR. The rela- tionships between antibiotic drugs, AR bacteria, and AR genes in agroecosystems are complex. Sometimes, clear correlations are observed between drugs and resistance; this is the outcome that is generally expected. In the presence of more drugs, more resistance is observed (as measured by an increase in the number or types of AR bacteria and/or AR genes) (Knapp et al. 2010; Sancheza et al. 2016; Österberg et al. 2016). However, the presence of more drugs does not always correlate with more resistance in environmental settings (Ghosh and LaPara 2007; Dalkmann et al. 2012; Mantz et al. 2013; Jechalke et al. 2015).

Unlike assessments done in animals (Dorado-García et al. 2016), the complexities of natural systems confound efforts to identify direct causal relationships in manure, soil, water, and air (Franklin et al. 2016; Williams-Nguyen et al. 2016). Heavy metals, biocides, detergents, and iron deprivation also co-select for resistance genes (Seiler and Berendonk 2012). AR genes located on mobile elements are enriched indirectly via selection for other genes located on the same replicon (Alonso et al. 2001; Gillings et al. 2008). In addition, evidence suggests a role for antibiotics beyond simply inhibiting bacterial growth. Some bacteria use antibiotics as a carbon source (Dantas et al. 2008), and transcriptomics reveals the potential for antibiotics to serve as a signaling molecules, influencing stress response, motility, and biofilm formation (Romero et al. 2011). Thus, there are many possible functions of environmental bacteria that can potentially impact selection of resistance.

In addition to identifying terminology that has multiple definitions across the One Health partners, it is also useful to acknowledge and articulate the outcome of interest in environmental AR discussions. For example, given that AR occurs naturally in soil, and as a result of historical and current anthropogenic activities, does source of the target matter? The answer to this question depends on the outcome of interest. From the perspective of reducing risk, and reducing the occurrence of untreatable infections in humans and animals, the answer is no. Regardless of how the AR bacteria or AR genes got into the agroecosystem-whether naturally occurring or the result of anthropogenic activities-the goal is to limit their transfer out of the system. Knowing the background and baseline levels of resistance is important for measuring the impact of management and mitigation practices, but it is not mandatory to source-track individual bacteria or genes. In contrast, when assessing agricultural AR risk from a regulatory perspective, it is critical to distinguish between $\mathrm{AR}$ bacteria and AR genes that are the result of current 
anthropogenic activities, from AR bacteria and AR genes that occur naturally, or that were part of the baseline resistance on a farm. Beginning discussions by clarifying goals is another technique that can improve One Health teams.

Complexities of the agroecosystem environment continue to confound efforts to define risk associated with AR across the farm to table continuum. Continuing efforts to harmonize the lexicon and to frame risk and define relevant outcomes across the branches of One Health professionals will inform and strengthen One Health efforts.

\section{ACKNOWLEDGMENTS}

Our thanks are extended to Dr. Dave Knabel for helpful comments on the manuscript. This work was funded by USDA-ARS National Program 212 Soil and Air Research Program.

\section{Open Access}

This article is distributed under the terms of the Creative Commons Attribution 4.0 International License (http:// creativecommons.org/licenses/by/4.0/), which permits unrestricted use, distribution, and reproduction in any medium, provided you give appropriate credit to the original author(s) and the source, provide a link to the Creative Commons license, and indicate if changes were made.

\section{REFERENCES}

Aga DS, Lenczewski M, Snow DD, Muurinen J, Sallach J, Wallace J (2016) Challenges in the measurement of antibiotics and in evaluating their impacts in agroecosystems: a critical review. J. Environ. Qual. 45:407-419. https://doi.org/10.2134/ jeq2015.07.0393

Agar M (2006) Culture: Can you take it anywhere? International Journal of Qualitative Methods 5(2). http://www.ualberta.ca/ $\sim \mathrm{ijqm} /$

Allen HK, Donato J, Wang HH, Cloud-Hansen KA, Davies J, Handelsman J (2010) Call of the wild: antibiotic resistance genes in natural environments. Nature Reviews Microbiology 8:251259

Alonso A, Sanchez P, Martinez JL (2001) Environmental selection of antibiotic resistance genes. Environmental Microbiology 3:1-9. https://doi.org/10.1046/j.1462-2920.2001.00161.x

Amarakoon ID, Zvomuya F, Sura S, Larney FJ, Cessna AJ, Xu S, McAllister TA (2016) Dissipation of antimicrobials in feedlot manure compost after oral administration versus fortification after excretion. Journal of Environmental Quality 45:503-510. https://doi.org/10.2134/jeq2015.07.0408

Ashbolt NJ, Amézquita A, Backhaus T, Borriello P, Brandt KK, Collignon P, Coors A, Finley R, Gaze WH, Heberer T, Lawrence JR, Larsson DG, McEwen SA, Ryan JJ, Schönfeld J, Silley P, Snape JR, Van den Eede C, Topp EE (2013) Human health risk assessment (HHRA) for environmental development and transfer of antibiotic resistance. Environmental Health Perspectives 121:993-1001. https://doi.org/10.1289/ehp.1206316

Barrett MA, Bouley TA (2015) Need for enhanced environmental representation in the implementation of One Health. EcoHealth $12: 212-219$

Berendonk TU, Manaia CM, Merlin C, Fatta-Kassinos D, Cytryn E, Walsh F, Bürgmann H, Sorum H, Norström M, Pons M, Kreuzinger N, Huovinen P, Stefani S, Schwarts T, Kisand V, Baquero F, Martínez JL (2015) Tackling antibiotic resistance: the environmental framework. Nature Reviews Microbiology 13:310-317. https://doi.org/10.1038/nrmicro3439

Berry Wendell (1990) "The Pleasures of Eating" from What are people for?, Berkeley, CA: Counterpoint Press

Brooks JP, Adeli A, McLaughlin MR (2014) Microbial ecology, bacterial pathogens, and antibiotic resistant genes in swine manure wastewater as influenced by three swine management systems. Water Research 57:96-103

Centers for Disease Control and Prevention (2013) Antibiotic resistance threats in the United States. U.S. Department of Health and Human Services. https://www.cdc.gov/drugresistance/ threat-report-2013/pdf/ar-threats-2013-508.pdf.

Chambers L, Uang Y, Littier H, Ray P, Zhang T, Pruden A, Strickland M, Knowlton K (2015) Metagenomic analysis of antibiotic resistance genes in dairy cow feces following therapeutic administration of third generation cephalosporin. PLoS One. https://doi.org/10.1371/journal.pone.0133764

Cheng VCC, Wong SC, Chen JHK, So SYC, Wong SCY, Ho PL, Yuen KY (2018) Control of multidrug-resistant Acinetobacter baumannii in Hong Kong: Role of environmental surveillance in communal areas after a hospital outbreak. American Journal of Infection Control 46:60-66

Clinical and Laboratory Standards Institute (2017) Performance standards for antibiotic disk susceptibility tests: approved standard, 27th ed. 1-56238-804-5 CLSI, Wayne, PA

Cook KL, Netthisinghe AM, Gilfillen RA (2014) Detection of pathogens, indicators, and antibiotic resistance genes after land application of poultry litter. Journal of Environmental Quality 43:1546-1558

Dalkmann PM, Broszat C, Siebe E, Willaschek T, Sakinc J Huebner, Amelung W, Grohmann E, Siemens J (2012) Accumulation of pharmaceuticals, enterococcus, and resistance genes in soils irrigated with wastewater for zero to 100 years in central Mexico. PLoS One. https://doi.org/10.1371/journal.pone.0045397

Dantas G, Sommer MO, Oluwasegun RD, Church GM (2008) Bacteria subsisting on antibiotics. Science 320(5872):100-103

Dorado-García A, et al. (2016) Quantitative assessment of antimicrobial resistance in livestock during the course of a nationwide antimicrobial use reduction in the Netherlands. Journal of Antimicrobial Chemotherapy 71(12):3607-3619. https://doi.org/10.1093/jac/dkw308

Durso LM, Cook KL (2014) Impacts of antibiotic use in agriculture: What are the benefits and risks? Current Opinion in Microbiology 19(37-44):2014

Durso LM, Schmidt AM (2018) Antimicrobial resistance related to agricultural wastewater and biosolids. In: Antimicrobial 
Resistance in the Wastewater Treatment Process, Keen PL, Fugère R (editors), Hoboken, NJ: John Wiley \& Sons, Inc.

Durso LM, Wedin D, Gilley JE, Miller DN, Marx DB (2016) Assessment of selected antibiotic resistances in ungrazed native Nebraska prairie soils. Journal of Environmental Quality 45:454462. https://doi.org/10.2134/jeq2015.06.0280, https://dl.science societies.org/publications/jeq/pdfs/0/0/jeq2015.06.0280

Fausey C, Boroditsky L (2010) Subtle linguistic cues influence perceived blame and financial liability. Psychonomic Bulletin \& Review 17(5):644-650. https://doi.org/10.3758/PBR.17.5.644

Fausey CM, Matlock T (2011) Can grammar win elections? Political Psychology 32(4):563-574. https://doi.org/10.1111/j.14679221.2010.00802.x

Finley RE, Ziobro HR (1966) The manufacturing man and his job. In: The Manufacturing Manager's Skills, Markle WH (editor), (Stainless Processing Company, Chicago, Illinois), Start Page 15, Quote Page 18, Published by American Management Association, Inc., New York

Fosberg KJ, Reyes A, Wang B, Selleck EM, Sommer MOA, Dantas G (2015) The shared antibiotic resistome of soil bacteria and human pathogens. Science 337:1107-1111

Franklin AM, Aga DS, Cytryn E, Durso LM, McLain JE, Pruden A, Roberts MC, Rothrock MJ, Snow DD, Watson JE, Dungan RS (2016) Antibiotics in agroecosystems: introduction to the special section. Journal of Environmental Quality 45:377-393. https://doi.org/10.2134/jeq2016.01.0023

Ghosh S, LaPara TM (2007) The effects of subtherapeutic antibiotic use in farm animals on the proliferation and persistence of antibiotic resistance among soil bacteria. ISME 1:191203

Gillings M, Boucher Y, Labbate M, Holms A, Krishnan S, Holley M, Stokes HW (2008) The evolution of the Class 1 integrons and the rise of antibiotic resistance. Journal of Bacteriology 190:5095-5100

Groysberg B, Slind M (2012) Leadership Is a Conversation. Harvard Business Review 90(6). View Details

Jechalke S, Broszat M, Lang F, Siebe C, Smalla K, Grohmann E (2015) Effects of 100 years wastewater irrigation on resistance genes, class 1 integrons and IncP-1 plasmids in Mexican soil. Frontiers in Microbiology 6:163

Jia SY, Shi P, Hu Q, Li B, Zhang T, Zhang XX (2015) Bacterial community shift drives antibiotic resistance promotion during drinking water chlorination. Environmental Science \& Technology 49:12271-12279

Jørgensen PS, Wernli D, Folke C, Caroll SP (2017) Changing antibitoic resistance: sustainability transformation to a promicrobial planet. Current Opinion in Environmental Sustainability 25:66-76

Knapp CW, Zhang W, Sturm BS, Graham DW (2010) Differential fate of erythromycin and beta-lactam resistance genes from swine lagoon waste under different aquatic conditions. Environmental Pollution 158:1506-1512

Knapp B, Bardent R, Bernabeu MO, Bordas R, Bruna M, Calderhead B, Cooper J, Fletcher AG, Groen D, Kuijper B, Lewis J, McInerny G, Minssen T, Osborne J, Paulitschke V, PittFrancis J, Todoric J, Yates CA, Gavaghan D, Deane CM (2015) Ten simple rules for a successful cross-disciplinary collaboration. PLoS Computational Biology 11(4):e1004214. https:// doi.org/10.1371/journal.pcbi.1004214

Lammie SL, Hughes JM (2016) Antimicrobial resistance, food safety, and one health: the need for convergence. Annual Review of Food Science and Technology 7:287-312
Lederach JP (1991) "Of nets, nails, and problems: the folk language of conflict resolution in a central American setting". In: Conflict Resolution: Cross-Cultural Perspectives, Avruch K, Black PW, Scimecca JA (editors), New York, Westport, Connecticut, London: Greenwood Press, pp 165-186

Mantz AR, Miller DN, Spiehs JJ, Woodbury BL, Durso LM (2013) Persistence of erythromycin resistance gene $\operatorname{erm}(\mathrm{B})$ in cattle feedlot pens over time. Agriculture, Food \& Analytical Bacteriology 3(4):312-326

Marti R, Tien YC, Murray R, Scott A, Sabourin L, Topp E (2014) Safely coupling livestock and crop production systems: how rapidly do antibiotic resistance genes dissipate in soil following a commercial application of swine or dairy manure? Applied and Environmental Microbiology 80:3258-3265

McKinney CW, Loftin KA, Meyer MT, Davis JG, Pruden A (2010) Tet and sul antibiotic resistance genes in livestock lagoons of various operation type, configuration, and antibiotic occurrence. Environmental Science and Technology 44:6102-6109

McLain JE, Cytryn E, Durso LM, Young S (2016) Culture-based methods for detection of antibiotic resistance in agroecosystems: advantages, challenges, and gaps in knowledge. Journal of Environmental Quality 45(2):432-440. https://doi.org/10.2134/ jeq2015.06.0317

Österberg J, Wingstrand A, Nygaard Jensen A, Kerouanton A, Cibin V, Barco L, Denis M, Aabo S, Bengtsson B (2016) Antibiotic resistance in Escherichia coli from pigs in organic and conventional farming in four European countries. PLoS One. https://doi.org/10.1371/journal.pone.0157049

Pruden A, Larsson DGJ, Amézquita A, Collingnon P, Brandt KK, Graham DW, Lazorchak JM, Suzuki S, Silley P, Snape JR, Topp E, Zhang T, Zhu YG (2013) Management options for reducing the release of antibiotics and antibiotic resistance genes to the environment. Environmental Health Perspectives 121:878-885

Qiao M, Ying GG, Singer AC, Zhu YG (2018) Review of antibiotic resistance in China and its environment. Environment International 110:160-172

Ramirez R, Selsky J, van der Heijden K (2008) Business Planning in Turbulent Times: New Methods for Applying Scenarios, London: Earthscan

Robinson TP, Bu DP, Carrique-Mas J, Fevre EM, Gilbert M, Grace D, Hay SI, Jiwakanon J, Kakkar M, Laxminarayan SKR, Lubroth J, Magnusson U, Ngoc PT, Van Boeckel TP, Woolhouse MEJ (2016) Antibiotic resistance is the quintessential One Health issue. Transactions of the Royal Society of Tropical Medicine and Hygiene 110:377-380. https://doi.org/10.1093/trstmh/trw048

Romero D, Traxler MF, Lopez D, Kolter R (2011) Antibiotics as signal molecules. Chemical Reviews 111:5492-5505

Sancheza HM, Echeverria C, Thulsiraj V, Zimmer-Faust A, Flores A, Laitz M, Healy G, Mahendra S, Paulson SE, Zhu Y, Jay JA (2016) Antibiotic resistance in airborne bacteria near conventional and organic beef cattle farms in California, USA. Water, Air, and Soil Pollution 227:280. https://doi.org/10.1007/s11270016-2979-8

Sandberg KD, LaPara TM (2016) The fate of antibiotic resistance genes and class 1 integrons following the application of swine and dairy manure soils. FEMS Microbiology Ecology 92:fiw001

Seiler C, Berendonk TU (2012) Heavy metal driven co-selection of antibiotic resistance in soil and water bodies impacted by agriculture and aquaculture. Frontiers in Microbiology. https:// doi.org/10.3389/fmicb.2012.00399 
Subbiah M, Mitchell SM, Call DR (2016) Not all antibiotic use practices in food-animal agriculture affortd the same risk. Journal of Environmental Quality 45:618-629

Sullivan S, Mccann E, De Young R, Erickson D (1996) Farmers' attitudes about farming and the environment: a survey of conventional and organic farmers. Journal of Agricultural and Environmental Ethics 9:123-143

Sutherland MA, Webster J, Sutherland I (2013) Animal health and welfare issues facing organic production systems. Animals 3:1021-1035

Syrengelas KG, DeLong KL, Grebitus C, Nayga RM Jr (2017) Is the natural label misleading? Examining consumer preferences for natural beef Applied Economic Perspectives and Policy. https:// doi.org/10.1093/aepp/ppx042

Thomas J, McDonagh D (2013) Shared language: towards more effective communication. Australasian Medical Journal 6:46-54

Thompson JL (2009) Building collective communication competence in interdisciplinary research teams. Journal of Applied Communication Research 37(3):278-297
Thomson W (1889) Popular lectures and addresses, Vol 1 constitution of matter. London: Macmillan and Co, pp 73

Topp E, Larsson DGJ, Miller DN, Van den Eede C, Virta MPJ (2018) Antimicrobial resistance and the environment: assessment, advances, gaps and recommendations for agriculture, aquaculture and pharmaceutical manufacturing. FEMS Microbiology Ecology 94:185. https://doi.org/10.1093/femsec/fix185

Wilkinson A, Eidinow E (2008) Evolving practices in environmental scenarios: a new scenario typology. Environmental Research Letters 3:045017

Williams-Nguyen J, Sallach BJ, Bartelt-Hunt S, Boxall A, Durso LM, McLain JE, Singer RS, Snow DD, Zilles JL (2016) Antibiotics and antibiotic resistance in agroecosystems: state of the science. Journal of Environmental Quality 45:394-406. https:// doi.org/10.2134/jeq2015.07.0336

USDA (2006) National organic program. 7 CFR 205.236. 2006 